\title{
Return on Investment in Sports Marketing Initiatives: A Study Focusing on a Brazilian Soccer Team
}

\author{
Laura Mendes Louzada ${ }^{1}$, André Lucirton Costa $^{1} \&$ Janaina de Moura Engracia Giraldi ${ }^{1}$ \\ ${ }^{1}$ Department of Business Administration, University of São Paulo, Ribeirão Preto, Brazil \\ Correspondence: Janaina de Moura Engracia Giraldi, Associate Professor of Marketing and Management, \\ Department of Business Administration, University of São Paulo, Av. Bandeirantes 3900, Monte Alegre, Ribeirão \\ Preto (SP), CEP: 14040-905, Brazil. Tel: 55-16-3602-3903. E-mail: jgiraldi@usp.br
}

Received: September 4, 2014

Accepted: September 11, $2014 \quad$ Online Published: September 14, 2014

doi:10.5430/ijba.v5n5p71

URL: http://dx.doi.org/10.5430/ijba.v5n5p71

\begin{abstract}
Our study analyzes the sports marketing environment, focusing specifically on soccer, in order to determine how a soccer team marketing department operates in terms of organization, planning, development of activities, and professionalization. The method utilized was based on a Brazilian soccer team case study. Data were obtained by means of a semi-structured interview with one of the members of the Brazilian soccer team marketing department, and complementary data were collected from material supplied by the respondent, from secondary sources and from the Brazilian soccer team website. It was possible to verify how marketing activities are developed by the club and to compare it with what is established by the theory, that is, how to plan and perform sports marketing activities. Moreover, it was possible to propose a structure for evaluating the club marketing performance by identifying the areas responsible for the best results, particularly in terms of financial returns.
\end{abstract}

Keywords: planning, competitiveness, marketing plan, sports marketing, soccer

\section{Introduction}

According to Morrow and Howieson (2014) "the business transformation of football and its clubs over the past 2 decades or so has implications for managers". The authors argue that managers have inadequate preparedness to deal with nonfootball matters, as financial, budgeting, club politics and management in general. However, these tools had become pervasive in soccer clubs.

Hyatt, Sutton, Foster and McConnell (2013) agreed that something must be done to get sports fans interested in the real-league standings: "Unless sport managers are prepared to play games in front of empty stadiums for the sole purpose of generating statistics to be consumed by fantasy players and video gamers".

Although recognizing its local, national and global importance, Fullerton and Merz (2008) agree that so far no consensus in relation to the exact meaning of sports marketing has been established. For Pitts and Stotlar (2002), it is the function responsible for helping the sports business identify products and/or services the sports consumer wishes and/or needs.

In this context, considering soccer profissionalization where management is becoming quite similar to that of a business company, the study of each of the corporate functions (finance, marketing, human resources, technology, and operations) becomes extremely relevant. Specifically in the case of marketing, we could verify that soccer clubs are concerned about channeling their initiatives towards this area, which is responbile for a good portion of their revenue. However, according to Blann and Armstrong (2005), the sports marketing should go beyond advertising and public relations.

Despite the fact that the Brazilian soccer market is still small when compared to the global soccer market, it already has a significant representation. According to Leoncini and Silva (2005), it is a market that moves approximately 250 billion dollars per year in the global economy. The Brazilian soccer market, although representing less than $1 \%$ of this total value, has shown an impressive growth in recent years, and soccer clubs have an increasing need to plan their activities as a means of ensuring their competitiveness, attracting fans, and strengthening their brands. 
After checking what is approached by the sports marketing theory and comparing it to what actually happens inside soccer clubs, we have got to the conclusion that the present paper can make a contribution to the activities developed by the market department of a soccer club.

From this point on, we hope it will be possible to develop a model of feasible actions concerning the sports marketing of a soccer club, including actions which are already in place and those which would contribute to enhance the club image; moreover, it would be interesting to verify the impact of marketing actions upon the results obtained by the club, as well as the impact of such actions upon the club brand. By checking the marketing activities carried out by soccer teams, theoretical concepts might be identified and developed. By doing so we would make a theoretical contribution to the development of the theme.

The present paper is structured as follows: theoretical review; methodology; presentation and analysis of results; final considerations; and references. The theoretical review is divided into two parts: the first focus on the sports marketing as a whole; the second, on the sports marketing specific to the soccer market.

\section{The Sports Marketing Plan}

According to Pitts and Stotlar (2002), the sports administration may include every person, activity, business and organization engajed in producing, supporting, promoting and dealing with sports products, including those related to fitness and recreation. For these two authors, the sports industry represents the market where the products offered to consumers are related to sports, fitness, recreation or leasure, and may include activities, assets, services, people, places or concepts. Thus, the sports marketing as a part of sports dministration should develop its activities within the sports industry.

Concerning the sports environment, Gray and McEvoy (2005) define the sports marketing as the application of marketing principles and processes when offering products and services to participants and viewers belonging to the world of sports. Soares, in turn, (2007a) attributes to the sports marketing a double role: satisfying the marketing needs and giving fans the opportunity to enjoy their passion for a given sport.

Bauer, Sauer and Schmitt (2005) consider that "sport companies have to be progressive service sellers in order to successfully compete with other leisure offers". In other words, it is important to establish relationship management activities with fans and stakeholders. Teams have to support fan clubs and offer fans the opportunity to communicate with the team. In this sense, the authors argue that the brand is considered the most important asset of sport clubs.

Generation of a brand concept within the sports market demands the development of attributes which would be responsible for differentiating the brand, with potential to attract cheerers/consumers (Rein, Kotler \& Shields, 2006). Consequently, according to Kotler and Keller (2009), branding takes place when products and services related to a given sports team utilize the team name as their brand, that is, when a sports brand concept is created and, consequently, has potential to attract cheerers.

Rein (2006) argues that sports products should not focus only on the promotion of their attributes through the results obtained in championships. Brand recognition should happen whatever the results. Thus, the author points out that the market demands different ways of attractitn consumers, and being familiar with the market will allow the creation of a bond with fans, thus reducing dependence on victories.

From Afif (2000) standpoint, activities related to sports marketing should be preceded by a marketing plan defined as a strategic document which would serve as a guide for marketing efforts.

Soares (2007a) argues that a sports marketing plan should be developed and assessed according to the following stages: identification of the sports business mission and objectives; analysis of the situation, including verification of the cooperative, competitive, economic, social, political and legal environment, identification of their respective impacts on marketing, thus allowing identification of opportunies and threats; sports marketing research in order to facilitate the decision making process; analysis of the sports consumer and of competition in the sports industry in order to get familiar and understand both consumers and potential competitors; segmentation of consumers and industry as the primary way to overcome the intangible nature of their products; definition of the operating strategy, including the targeted market, mix of the sports marketing, that is, another P should be added to the 4 Ps, which would then become 5: product, price, point, promotion, and public relations. The fifth "P" involves the media, always present in the promotion of sports activities. From this point on, the strategy of the marketing administration could be developed by means of management, implementation, and assessment. 
Similarly to marketing plan, Garland, Brooksbank and Werder (2011) addresses the strategic marketing as a tool that "can be defined as an ongoing, organisation-wide and customer-led planning approach that facilitates optimal organisational responses to the fast changing and increasingly volatile modern business environment".

According to Kotler and Keller (2009), control of the marketing plan is fundamental to describe the way the activities would be monitored. The indicators shown in Figure 1 were chosen to allow evaluation of the results obtained by the marketing department and then compare them with the results obtained by the organization as a whole.

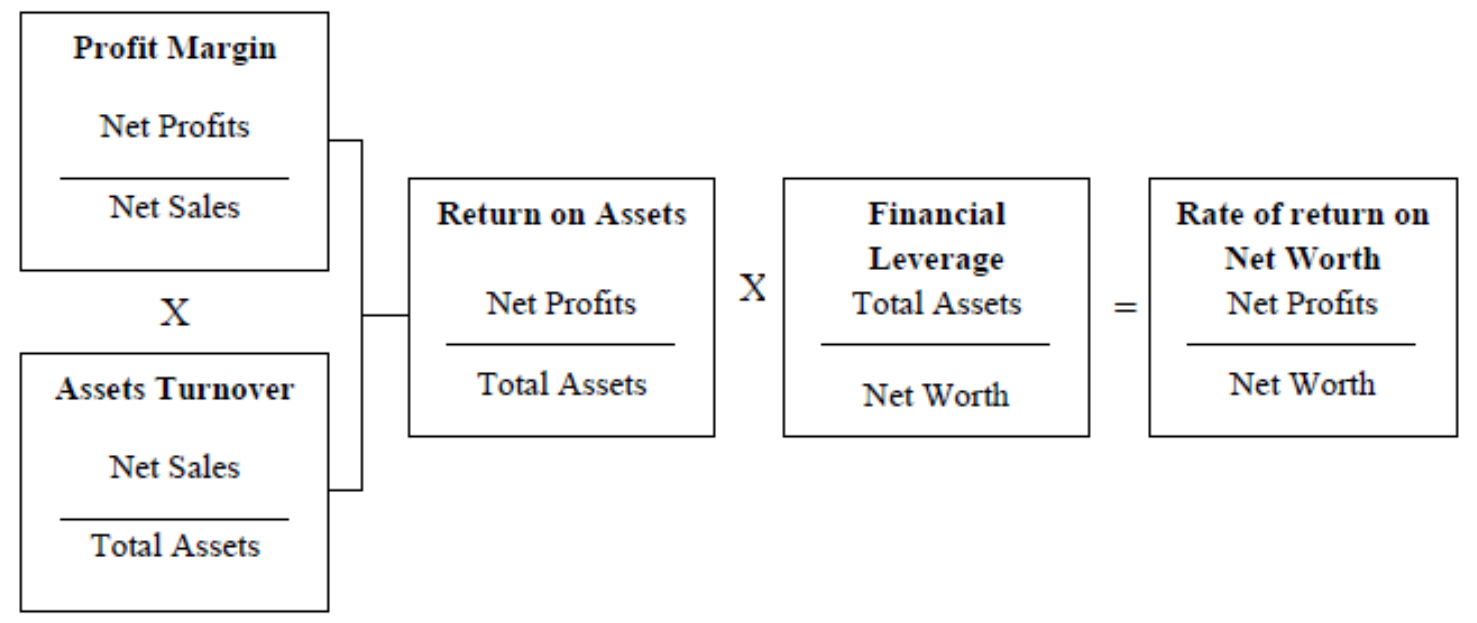

Figure 1. Financial model of return on net worth

Source: Adapted from Kotler and Keller (2009, p. 120).

For a company, the profit margin represents the generation of surplus (or deficit) resources Asset turnover is the capacity of generating revenues by mobilizing a given amount of resources applied in assets; the return on assets measures the generation of a surplus revenue according to the costs and expenses incurred, considering the total capital invested (Matias 2007). Finally, Brealey and Myers (2003) define the financial leverage as the level of indebtedness and the rate of return on net worth as the return obtained from the cost of the capital opportunity.

After identifying the total revenues generated by the marketing, a profitability analysis should be performed by identifying and attributing the functional expenses to the marketing variables and by preparing a statement of results for each variable as a means of checking the performance of each of the marketing channels and by evaluating their impact upon total marketing revenues. (Kotler \& Keller, 2009)

For purposes of minimizing potential impacts resulting from the fact that we do not know each cost and expense upon attributing them to the marketing variables, departmentalization will be approached in the present paper. According to Martins (2003), department is the smallest administrative unit where homogeneous activities are developed. Thus, the marketing area can be considered a Service Department where costs are allocated to the services provided.

\section{The Sports Marketing in Soccer}

From 1990 on, several changes in the Brazilian soccer administration environment have taken place in view of the increasing perception that soccer had potential to be treated as a business. Several soccer clubs started to establish partnership agreements with companies with the purpose of developing and managing their activities, including marketing activities (Leoncini \& Silva, 2005).

Costa (2007) remarks that only in 1970 did the sports marketing start to be developed in the Brazilian territory. Specifically concerning soccer, the actual development of the marketing industry happend only in the late decades of the twentieth century, when the name of the company which sponsored the team was printed in the uniforms of the athletes as a means to raise money, and transmission rights upon sports events were negotiated with TV broadcasting stations.

Leoncini (2001) argues that when viewed as organizations, soccer clubs face the performance trade-off between the sports performance, that is, the victories, and the financial performance, that is, earning profits and reaching a financial balance. Thus, the sports performance depends on the expenditures with salaries paid to athetes, as well as on the generation of revenues provided by cheerers as participants of the consumer market, showing significant and directly 
proportional correlations. In other words, for a better sports performance, expeditures with salaries paid to athletes should be higher, thus revenues should also be higher (Leoncin \& Siva, 2005). In view of this, soccer club directors usually invest resources in hiring good soccer players, thus creating a good team, hoping to achieve positive results in championships and high revenues at the box office.

In this context, Kuper \& Szymanski (2009) quote the words of a British soccer coach: buying good soccer players for a price below their actual value will bring victories to the club; at the same time, there will be plenty of money to buy other good players; upon winning a larger number of games, a larger number of cheerers will be attracted to soccer stadiums and, consequently, will bring more money to the club. Leoncini \& Silva (2005), in turn, depict the Brazilian scenario in the following way: large expenditures with salaries and high investments in hiring are made aiming at forming a good team, but not always is due attention given to the generation of income in the market of fans.

Specifically in the case of soccer, today marketing tools are viewed as a means to help administrating soccer clubs, as they bring alternative revenues (Grellet, 2000). As main sources of revenue for a soccer club Soares (2007b) mentions the following: training and trading of athletes; TV broadcasting rights; events (games, shows); sponsoring companies; merchandising; cooperation given by the municipal government; and the social club. In addition, he attributes to sports idols the key role of promoting a given brand within the sports market; he sees the athletes as spokesmen of the market, responsible for communicating an image through their talent.

Brunoro and Afif (1997) consider the marketing department of a soccer club a fundamental channel for collecting resources and, like Soares (2007b), they also consider the sale of tickets, TV quotes, and sponsorship of uniforms and sports items the main soucers of revenues. The authors believe that one of the most important tasks to be accomplished by the marketing department is the negotiation of agreements with TV stations for broadcasting soccer games.

Considering sport consumers, Kim and Trail (2011) argue that they "are increasingly discontented and disconnected with sport organizations". The authors consider that researchers can improuve the situation, by implementing the view that sport marketing have to change from a traditional exchange paradigm to a relationship paradigm, reinforcing Bauer, Sauer and Schmitt (2005) thought: it is important to establish relationship management. Complementarly, Hyatt, Sutton, Foster and McConnell (2013) advocate that fans have to have greater participation in clubs decisions, ensuring the relationship paradigm.

According to Brunoro and Afif (1997), soccer should be understood as a product for sale; soccer clubs should be concerned about the preferences of their consumers, and should try to maintain the characteristics and the quality of the products they represent. The authors argue that every large soccer club represents a strong brand, due to its strong ties with cheerers; concerning this aspect, the difficulty faced by soccer clubs is to know how to identify the potential to explore their brands, particularly in relation to the ability to produce their licensed products and advertising campaigns. European soccer clubs are examples of clubs which know how to explore the marketing - they know how to commercialize from key rings to complete lines of outfits and sports clothes so that the cheerer actually spends a lot of money, not just buys small gifts as souvenirs of his/her sports club.

Budzinski and Stazer (2011) argue that clubs should make pricing strategies even more effective, seeking to attract more participation from consumer by making the game more TV-friendly. The strategies can envolve: introduce extra breaks, develop a TV-friendly format, attract media-friendly protagonists and vary the distribution of sport events.

According to Melo Neto (1998), the major asset a sports club has is the strength of its brand, which should be constantly exposed to the midia and associated with the achievement of important titles and victories, thus reinforcing the feelings the cheerer has towards his/her club and considering the brand of the "cherished team" in accordance with the degree of passion the cheerer-customer feels towards his/her club.

According to Grellet (2000), soccer is disseminated mainly through TV. In addition, another important marketing characteristic shown by major soccer teams is the massive number of cheerers their fan bases aggregate. Although some Brazilian soccer clubs - among them Corinthians and Flamengo, for example - have a number of cheerers far above that of the British soccer club Manchester United, from England, their economic conditions are far from being similar to those of the British team, due mainly to two factors: Manchester considers its cheerers as consumers of a product, that is, as clients of a brand that aims to make profits, and thus are given a unique treatement.

Brunoro and Afif (1997) understand that the structure of such department should comprise a manager who would be responsible for creating a team of advisors who would select licensed companies for the manufacture of products representing the club; a press advisor, who would be responsible for keeping the media informed on the stuff the marketing department is providing to the club; this person should also prepare promotional scripts for cheerers and 
club members. Activities related to promotional campaigns in soccer stadiums and communication vehicles should also be developed by the marketing department.

Kuper and Szymanski (2009) place the cheerers on the other side of the soccer market, they remain faithfull to their club even when it is defeated, and always manage to find other reasons for the poor performance shown by the soccer club, for example blaming the referee for the mistakes committed by the team. Thus, in terms of survival, the authors compare the soccer marketing with the marketing carried out by most companies: not always does the consumer loyalty depend on the quality of the product offered; cheerers remain loyal even when their club is undergoing a crisis and does not win a single victory.

Similarly, Blumrodt, Desbordes, and Bodin (2013) consider the entertainment part of the sport industry as an interesting show on the field, which includes high team performance. The authors argue that spectators nevertheless expect other accomplishments from the club, like corporate social responsibility, and specifically some essential elements of professional sport clubs' brand image: entertainment, stadium's quality and international competitiveness.

According to what can be observed, there is still a divergent thinking concerning the meaning of the sports marketing and the marketing utilized specifically in soccer. Moreover, those who participate in the sports market - more specifically in the Brazilian sports market - do not utilize the whole potential existing in each of the marketing activities developed by the marketing department.

\section{Methodology}

The exploratory research was utilized with the purpose of getting familiar with the problem so as to develop the case study which, according to Yin (2008), is the empiric investigation which explores a contemporary phenomenon within the context of real life. Thus, by utilizing a bibliographic survey as the theoretical basis, the Brazilian soccer team case was the object that allowed verifying how the theory is applied in real life.

The Brazilian soccer team was chosen as the unit to be analized because, according to what is published in the sports media, it is the Brazilian soccer club which carries out the largest number of marketing activities, and this enables a wider range of objects for analysis, in order to achieve the objectives of the present study. In addition, it is the soccer club which has the largest number of fans in the state of São Paulo and the second largest number of fans in Brazil, congretating more than 30 million cheerers (Sport Club Corinthians Paulista, 2010).

According to Stake (2000), the intrinsic case study is the object of the research as a means to dive deeply into the case at issue; in other words, by selecting the soccer club the Brazilian soccer team our purpose was to check the applicability of the sports marketing - how a marketing plan developed for a soccer club would work in terms of verifying the return on investment in marketing actions developed by the club.

Bellow follows some of the questions approached in the present study:

- Which and how can marketing tools be utilized by soccer clubs?

- How could the sports marketing plan/planning be accomplished?

- How would a model for analysis of the sports marketing department financial performance be designed?

- Which and how would the marketing tools be effectively utilized in the case under analysis?

- How would the marketing department accomplish its planning in this specific case?

- How could the marketing department contribute to maximize the financial results of the club under analysis?

- Which are the potential gaps/problems that might be faced by the marketing department in this specific case?

Out of the six sources of proof quoted by Yin (2008), the present study utilized five upon collecting data necessary for the case study. The documentation utilized includes data on the Brazilian soccer team published in the midia, as well as data used in 2009 and 2010 Sustainability Reports supplied by the respondent. For purposes of recording files and published statistics, we resorted to the Brazilian soccer team web site. The interview, direct observation and participant observation were carried out with the club marketing team during the interview conducted at the club headquarters in Parque São Jorge, in São Paulo.

\section{Presentation and Analysis of Results}

The results obtained in the case study are presented and analysed below, based on what is stated by the theory. First we give an overview of the Brazilian soccer team activities; then we describe the activities developed specifically by the club marketing department; finally we present the structure of the model proposed for evaluation of the Brazilian soccer team marketing department performance. 


\subsection{Description of the Unit under Analysis}

The Brazilian soccer team under analysis was founded on September $1^{\text {st }}$, 1910. In 1913 the amateur team joined Liga Paulista de Futebol (Paulista Soccer League) jointly with three other soccer clubs. The entrance of the club in official soccer and its consequent profissionalization happened in 1933 (Sport Club Corinthians Paulista, 2010).

A major milestone in the history of the club occurred in October 2007, when the new administration took office and ellected a new chairman of the board. The new board found a worrying economic-financial situation, and a renewal strategy had to be pursued.

With the changes implemented by the new administration, revenues at the closure of 2010 fiscal year reached $\mathrm{R} \$ 212,6$ million, $81 \%$ above those of 2008. Revenues resulting from the sale of tickets for games increased $77 \%$, a figure corresponding to R $\$ 29,4$ million (Sport Club Corinthians Paulista, 2010).

In 2007, the profile of the club revenues was broken down as follows: $53 \%$ were originated from the trading of athletes; $17 \%$, from TV quotes; $14 \%$, from sponsorship and advertising; $9 \%$, from the club social activities and amateur soccer; and $6 \%$ from the sale of tickets for games. Revenues generated by the club marketing department represented only $37 \%$ of total revenues (sale of tickets for games, sponsorship \& advertising, quotes referring to games broadcasted by TV).

Up to 2010, an increase in the number of activities developed by the club marketing department could be observed; there was also the inclusion of a new source of revenue linked to the marketing developed by the club: an initiative called Fiel Torcedor (Faithful Cheerer). From then on, the revenues under the responsibility of the club marketing department started to represent less than $64 \%$ of total revenues. In 2010 the revenues were broken down as follows: $26 \%$ from TV quotes; $22 \%$ from sponsorship and advertising; $18 \%$ from social activities and amateur soccer; $16 \%$ from the trading of athletes; $14 \%$ originated from collection in games; $\%$ from Fiel Torcedor, lotteries and other initiatives; $1 \%$ from awards gotten in championships (Sport Club Corinthians Paulista, 2010).

The soccer club new bylaws have been into force since September 2008; these bylaws are responsible for the establishment of legal grounds, thus allowing professionalization of the administration. Mission and values are represented by Seven Pillars: respect to our identity; respect to our culture; respect to our differences; respect to our traditions; propagation of the nation's values; get cheerers involved with the team; get cheerers involved with the club.

In 2010, the soccer club had 12,924 holder members, 8,806 dependent members, and over 30 million cheerers, representing the second largest fan base in Brazil and the largest in the state of São Paulo (Sport Club Corinthians Paulista, 2010). According to a survey published by the magazine Lance! (Ibope 2010), from 2004 to 2010 the number of the Brazilian soccer team cheerers increased by more than 1,8 million.

Although the Brazilian soccer team did not win any title between 2001 and 2010, the latter was the year when the club showed its greatest productivity in the professional games played: the percentage reached $62 \%$. Furthermore, 2010 was the year when the Brazilian soccer team, among the state of São Paulo soccer teams, had the largest number of games broadcasted by TV stations - 66 games played by the team were broadcasted (Sport Clube Corinthians Paulista, 2010).

A research conducted by Crowe Horwath RCS consulting firm where the Brazilian soccer team studied shows the most valuable brand among Brazilian soccer clubs, with a value of $\mathrm{R} \$ 749,785$ milion in 2010 . The club believes that the enhancement of its brand is the result of a successful strategic plan implemented by the Brazilian soccer team Marketing Department along the last three years. Such enhancement allowed the soccer team to win the confidence of new partners, investors and other people interested in getting associated with the brand.

\subsection{The Brazilian Soccer Team Marketing Department}

The Brazilian soccer team Marketing Department was established in 2007. Before that all activities related to marketing were performed by an outsourced agency. At present there isn't a formal structure to carry out the necessary tasks, and everyone gives their contribution. Only the director of the department has well defined tasks; in addition to controlling and heading the marketing department, he is charge of negociating sponsorship contracts, and also takes care of the relationships between the club and the midia. Reporting to the director is the department manager; reporting to him/her, there are three coordinators and three trainees in the following areas: general/licensing; licensing and visual coordination/new projects. Some activities, although being internally controlled, are outsourced, such as for example $\mathrm{web} / \mathrm{mobile}$ service; the journalist responsible for the press office; technology of the system which controls the program SócioTorcedor.

The main activities developed by the marketing department, particularly in relation to the revenues generated, are the negotiation of transmission rights with TV broadcasting stations, collection of sums referring to the sponsorship of 
uniforms. Another important activity developed by this department is to take care of the club image. The marketing department does not receive a fixed annual amount as a compensation for such activities. Before becoming feasible, every project demands the search for a partner who will supply the resources necessary for its development and implementation. Ironically, marketing is the department which generates more revenues for the club.

At the end of every year all departments are supposed to account for the activities developed during the year so that the annual sustainability report is prepared. At the beginning of January the targets for each department are established. For the marketing department, however, the establishment of targets isnt't quite concrete in view of: a) lack of financial resources; b) high dependence on partnerships for the development of projects; c) unpredictability of events in the soccer market; d) high dynamism of the activities involved; e) short deadlines for achieving these targets; f) frequent changes in the environment.

Comparing Brazilian soccer clubs, the Brazilian soccer team studied is among those which receive the highest sums from their sponsors. The largest sponsor is under an agreement which was signed at the beginning of 2005 and shall remain in force up to 2014. In 2010, out of the total $\mathrm{R} \$ 47$ million (Note 1) collected by the club with sponsorship and advertising, this sponsor contributed with $\mathrm{R} \$ 13.9$ million (Note 2). In addition, this partner provides around $\mathrm{R} \$ 4.5$ million per year in sports items upon channeling to the club.

The shops Poderoso Timão sell products licensed by the club, and are considered the "apple of the eyes" of the Brazilian soccer team marketing department. The project started in October 2008. In 2010 the chain comprised 105 shops that operates as franchising. Their overall invoicing has already surpassed $\mathrm{R} \$ 109$ million. The club has control over the sales accomplished by each shop by means of an outsourced information system. Information on sales accomplished by each franchised shop is transmitted to the marketing department on a daily basis. In addition to these franchised shops, the club has a virtual store - www.shoptimao.com.br - (Sport Club Corinthians Paulista, 2010).

Contact between franchisees and the Brazilian soccer team marketing department is constant. This allows the club to identify which new products could be launched and to obtain statistic data. For example, when the club is winning a game, the cheerers are encouraged to buy products bearing the club's brand. As opposed to what would be imagined, when the team is undergoing a bad phase, the cheerers have the tendency to help the club by buying a larger quantity of products bearing the team's brand. On the other hand, when the team is classified in the center of the table, the cheerers do not feel any motivation to buy. Another great advantage provided by the shops is that they reduce commercialization of pirated products.

The Brazilian soccer team licensed products comprise more than 4 thousand items. At the beginning the club tried to find companies which might establish licensing agreements with them; today, due to the high number of items offered and to their great acceptance, it is the club that is searched by companies interested in establishing this kind of partnership. The marketing department receives the proposals, analyses them and either approves or refuses them. The Brazilian soccer team receives a given amount in royalties (Note 3), and the licensee receives a percentage upon the sales accomplished.

The fan bases are also a concern of the club marketing department. The club recognizes the existence of five large fan bases. Each fan base has an identification card for control, and the main advantage of belonging to a fan base is at the time of buying tickets. The fan bases represent the most engajed and passionate cheerers, the so called fanatic fans (Note 4). At first it may seem easier for the marketing to please a passionate fan. Nevertheless, the department itself considers that the organized fan bases demand much more efforts to be pleased when compared with fans who are not involved. According to what is argued by Tapp (2004), there are the organized fan bases with fanatic and loyal cheerers; on the other hand, not always will the cheerer be wholeheartedly loyal to the club he/she has elected.

Launched in 2008, today the program Fiel Torcedor has 75 thousand associates; out of this number, 50 thousand are active members which purchase tickets/products and take advantage of the benefits offered by each of the three types of packages (Note 5) (my life, my story, my dear love). The idea is that this number increases and becomes the major part of the fan bases. The club would then have a better control over the sale of tickets and over the stadiums during the games, and this would also contribute to increase the fans loyalty.

When the soccer player Ronaldo was hired, the Brazilian soccer team brand was greatly enhanced. He contributed to increase the team's visibility in the international midia, in addition to bringing to the club massive resources generated by sponsorships and advertising campaigns. At the beginning the club was entitled to $50 \%$ of the rights on the athlete image.

In December 2010, the Brazilian soccer team established a partnership with PoupaFarma drugstores and with Neo Química (Note 6), and openned its first drugstore in Parque São Jorge, called "Farma Timão". Poupafarma chain is in 
charge of managing the drugstores; the chain is known for commercializing products oriented to low class people. Some of the products sold, such as sterile cotton, toilete soap and toothpaste, are licensed under the club brand.

In partnership with TV+, Corinthians TV channel (TVC) started its operations on March $1^{\text {st }}, 2011$, that daily programming includes live training by the professional team, post-training collective interviews, volleyball games, and games played by basic categories. In addition, the Brazilian soccer team has four publications: the magazine Chute Inicial (Initial Kick), which focus on the chain of soccer schools for kids; magazine Corinthians Mag, which deals with general subjects related to the club; the weekly newspaper O Fiel (The Faithful), and the magazine Nação Corinthians (Sport Club Corinthians Paulista, 2010).

With the restructuring of its administration, which is also responsible for the creation of the marketing department, the Brazilian soccer team demonstrated the capacity of the sports marketing in terms of identifying products/services which attract cheerers, corroborating what is defended by Pitts and Stolar (2002). Regardless of its victories, the club started seeking the attraction of fans by creating the program "Fiel Torcedor"; by acquiring knowledge of the market through "Poderoso Timão" shops; and by the values upheld in the club seven pillars. The team is also concerned about the loyalty of its cheerers and the enhancement of its brand.

\subsection{Development of a Model for the Marketing Department}

Table 1 indicates some values which will be necessary to assess the financial performance of the activities developed by the Brazilian soccer team, taking into consideration the model proposed by Kotler and Keller (2009) previously presented.

Table 1. Financial indicators

\begin{tabular}{|c|c|c|c|}
\hline & 2010 & 2009 & 2008 \\
\hline Net Profit & $\mathrm{R} \$ 3,477,000.00$ & $\mathrm{R} \$ 4,043,000.00$ & $\mathrm{R} \$ 12,035,000.00$ \\
\hline Net Sales & $\mathrm{R} \$ 166,230,000.00$ & $\mathrm{R} \$ 143,729,000.00$ & $\mathrm{R} \$ 93,361,000.00$ \\
\hline Total Assets & $\mathrm{R} \$ 430,591,000.00$ & $\mathrm{R} \$ 359,181,000.00$ & $\mathrm{R} \$ 307.660 .000,00$ \\
\hline Net Worth & $\mathrm{R} \$ 62,014,000.00$ & $\mathrm{R} \$ 58,322,000.00$ & $\mathrm{R} \$ 52,496,000.00$ \\
\hline
\end{tabular}

Source: Prepared by the authors based on data from Sport Club Corinthians 2009 and 2010 financial statements (Note 7).

Figure 2 ilustrates the Brazilian soccer team model of financial return. Each frame shows three values: the first represents year 2010; the second, year 2009; and the third, year 2008.

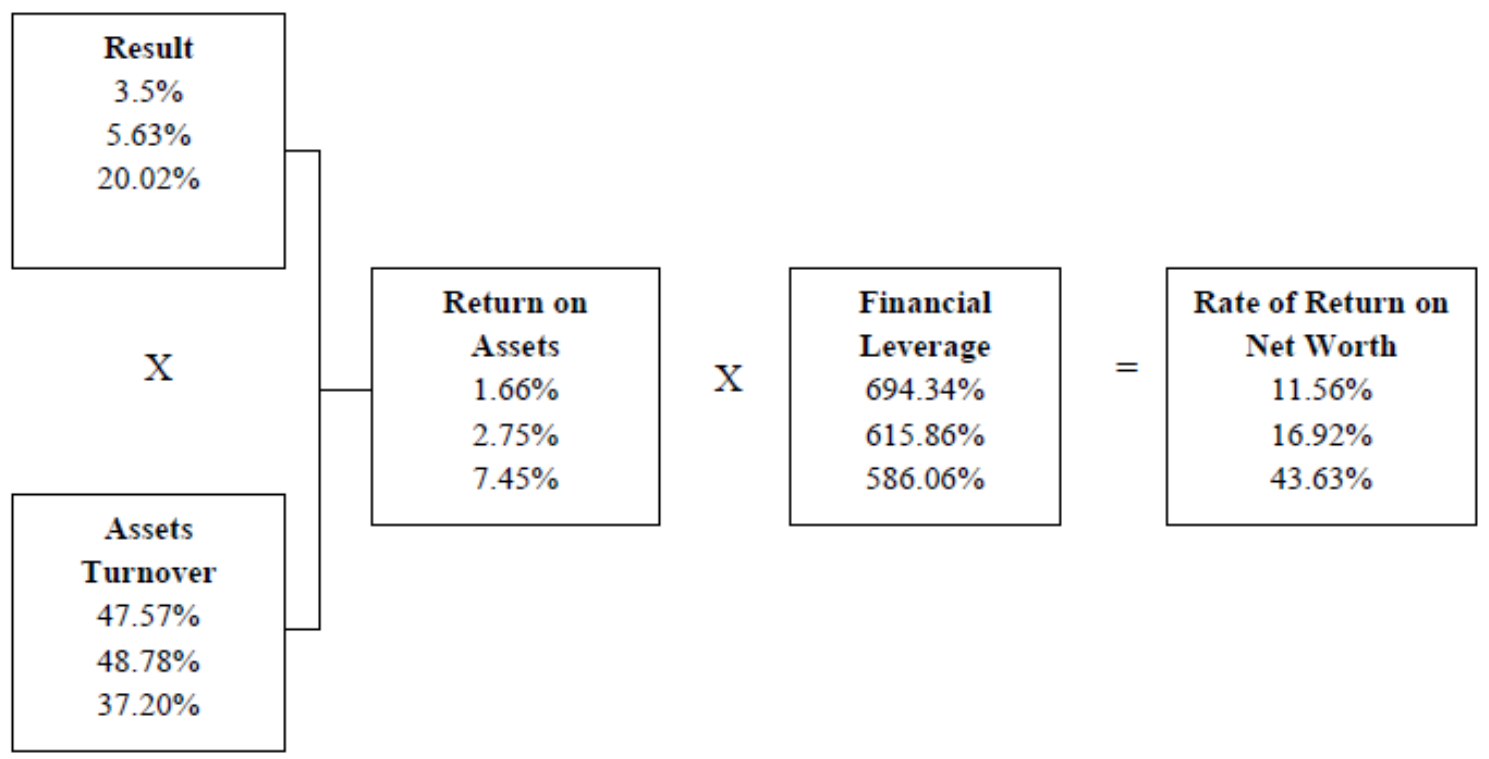

Figure 2. The Brazilian soccer team financial model of return on investment in PL, in 2010

Source: Adapted from Kotler and Keller (2009, p. 120). 
By analysing the financial model from 2008 to 2010 we could observe that there was a reduction in the profit margin, that is, the result. Despite the increase in the revenues generated by the sales accomplished by the club, the net profit showed a reduction, as it can be seen in Table 1, thus reducing the profit margin which, according to what is defined by Matias (2007), showed the highest rate concerning the generation of surplus resources, reaching $20.02 \%$ in 2008 . On the other hand, from 2008 to 2009 assets turnover showed an increase, remaining almost stable from 2009 to 2010. Such increase was due to the fact that, proportionally, revenues generated by sales showed a higher increase when compared with total assets. Thus, according to Matias definition for assets turnover (2007), by mobilizing its assets at a rate of $48.78 \%$, in 2009 was showed a greater capacity to generate revenues.

The variation in return on assets, that is, the result of the profit margin and assets turnover, is due to changes in the referred indicators. In 2008 the return on assets was higher (7.45\%), due maily to higher profit margins which surpassed the increase in assets turnover concerning 2009 and 2010. Thus, 2008 was the year when the club generated greater surpplus revenues according to the costs and expenses incurred and to total capital invested. The financial leverage shows high percentages in all years, due to the fact that the values representing total assets are far larger than those representing net worth. The Brazilian soccer team shows a high indebtedness level, but at the same time has a high potential to generate future economic benefits originated from events that have already taken place, although the amount of its own resources are not so high.

Taking into consideration the product resulting from the return on assets and the financial leverage, we get the rate of return on net worth, whose percentage in 2008 was higher. In this case, the high profit margin impacted the rate of return on assets which, in turn, impacted the rate of return on PL, surpassing the higher values of other indices in 2009 and 2010. We could then come to the conclusion that 2008 net profit, the highest in the three years mentioned, was the major factor that contributed to the high rate of return on PL, called by Brealey and Myers (2003) rate of return on the cost of the opportunity, which indicates the return on the capital invested; that is, the activities developed by the club, including those related to marketing, are generating positive financial results. According to what could be observed, this is happening because the marketing activities developed by the club are the major responsible for the profits/results achieved by the club.

Table 2 indicates total revenues generated by the team, that is, the revenues generated by the marketing and the total percentage these revenues represent in the club total revenue.

Table 2. Breakdown of the Brazilian soccer team revenues

\begin{tabular}{lccc}
\hline & 2010 & 2009 & 2008 \\
\hline Total Revenue & $\mathrm{R} \$ 212,633,000.00$ & $\mathrm{R} \$ 149,516,557.00$ & $\mathrm{R} \$ 117,521,000.00$ \\
Revenues generated by Mkt & $\mathrm{R} \$ 145,800,000.00$ & $\mathrm{R} \$ 118,300,000.00$ & $\mathrm{R} \$ 70,600,000.00$ \\
\% of revenues generated by Mkt & $68.57 \%$ & $79.12 \%$ & $60.07 \%$ \\
\hline
\end{tabular}

Source: Prepared by authors based on data obtained from Sport Club Corinthians Paulista (2009 and 2010).

Breakdown of revenues generated by marketing is shown in Table 3, in percentages and identifies the revenues generated by marketing, broken down into six major groups. Nevertheless, costs and expenses are shown separately in the statements and financial results. When questioned, the marketing department did not explain how such breakdown takes place. So, upon developing the structure for assessing the Brazilian soccer team performance, we will apply the departmentalization theory, in order to identify which costs and expenses are incurred by the marketing department.

Table 3. Breakdown of the Brazilian soccer team marketing revenues

\begin{tabular}{lccc}
\hline & $\mathbf{2 0 1 0}$ & $\mathbf{2 0 0 9}$ & $\mathbf{2 0 0 8}$ \\
\hline Total Marketing Revenues & $\mathrm{R} \$ 145,800,000.00$ & $\mathrm{R} \$ 118.300 .000,00$ & $\mathrm{R} \$ \mathbf{7 0 . 6 0 0 . 0 0 0 , 0 0}$ \\
TV/Advertising & $37.72 \%$ & $34.15 \%$ & $36.26 \%$ \\
Nike Sponsorship & $9.53 \%$ & $13.78 \%$ & $7.08 \%$ \\
Sponsorship of Uniforms & $17.14 \%$ & $18.01 \%$ & $22.66 \%$ \\
Sócio-Torcedor & $1.03 \%$ & $4.14 \%$ & $0.14 \%$ \\
Licensing & $14.40 \%$ & $6.59 \%$ & $10.34 \%$ \\
Ticket Sales & $20.16 \%$ & $23.33 \%$ & $23.51 \%$ \\
\hline
\end{tabular}

Source: Prepared by authors based on data obtained from Sport Club Corinthians Paulista, 2009 and 2010. 
Table 4 indicates costs, operating and financial expenses incurred by the Brazilian soccer team according to 2009 and 2010 financial statements (Note 8).

Table 4. Costs and expenses incurred by the Brazilian soccer team

\begin{tabular}{lrrr}
\hline & \multicolumn{1}{c}{$\mathbf{2 0 1 0}$} & \multicolumn{1}{c}{$\mathbf{2 0 0 9}$} & \multicolumn{1}{c}{$\mathbf{2 0 0 8}$} \\
\hline Costs & $\mathrm{R} \$ 7,801,000$ & $\mathrm{R} \$ 5,847,000$ & $\mathrm{R} \$ 3,013,000$ \\
Operating Expenses & $\mathrm{R} \$ 189,249,000$ & $\mathrm{R} \$ 162,159,000$ & $\mathrm{R} \$ 129,421,000$ \\
Financial Expenses & $\mathrm{R} \$ 12,811,000$ & $\mathrm{R} \$ 7,631,000$ & $\mathrm{R} \$ 1,752,000$ \\
\hline
\end{tabular}

Source: Prepared by authors.

By considering the marketing department as a service department it will be possible to discriminate specific costs and expenses. For costs and expenses we will utilize the same percentage of total revenues used in Table 3; for example: if in 2010 the revenues generated by marketing represented $68.57 \%$ of total revenues, the same $68.57 \%$ will represent the percentage of costs and expenses in relation to total costs and expenses. Thus, Table 5 indicates the costs and expenses incurred specifically by the marketing department.

Table 5. Costs and expenses incurred by the Brazilian soccer team marketing department

\begin{tabular}{lrrr}
\hline & \multicolumn{2}{c}{$\mathbf{2 0 1 0}$} & \multicolumn{2}{c}{2009} & \multicolumn{1}{c}{$\mathbf{2 0 0 8}$} \\
\hline Costs & $\mathrm{R} \$ 5,349,055.89$ & $\mathrm{R} \$ 4,626,244.17$ & $\mathrm{R} \$ 1,810,040.76$ \\
Operating Expenses & $\mathrm{R} \$ 129,765,860.43$ & $\mathrm{R} \$ 128,302,912.30$ & $\mathrm{R} \$ 77,748,849.99$ \\
Financial Expenses & $\mathrm{R} \$ 8,784.355 .20$ & $\mathrm{R} \$ 6.037 .774,80$ & $\mathrm{R} \$ 1,052,502.96$ \\
Total Expenses & $\mathrm{R} \$ 138,550,215.63$ & $\mathrm{R} \$ 134,340,687.10$ & $\mathrm{R} \$ 78,801,352.95$ \\
\hline
\end{tabular}

Source: Prepared by authors.

Within the marketing department there are sectors related to the origin of revenues and also to the breakdown of activities, as shown in Table 3. Thus, each of the six sectors will be treated as a service department, and the percentages shown in Table 3 will be the basis for costs allocation. Following this reationale, Table 6 shows revenues, costs, gross margin, expenses and profit/loss incurred by each sector of the marketing department.

Table 6 represents the structure proposed for evaluating the Brazilian soccer team marketing department based on the net profit/loss generated by each of the following areas: TV/advertising, sponsorship, uniforms sponsorship, sócio-torcedor program (cheerer-member program), licensing, and ticket sales. After getting the results it is possible to verify how each of these areas contributed to the results obtained by the marketing department as a whole.

Table 6. Breakdown of the Brazilian soccer team marketing revenues

\begin{tabular}{|c|c|c|c|c|c|c|c|}
\hline & & $\begin{array}{c}\text { TV/Static } \\
\text { Advertasing }\end{array}$ & Sponsorship & $\begin{array}{c}\text { Uniforms } \\
\text { Sponsorship }\end{array}$ & Member-cheerer & Licencsing & $\begin{array}{c}\text { Collection in } \\
\text { games }\end{array}$ \\
\hline \multirow{3}{*}{ Revenue } & 2008 & $25,600,000$ & $5,000,000$ & $16,000,000$ & 100,000 & $7,300,000$ & $16,600,000$ \\
\hline & 2009 & $40,400,000$ & $16,300,000$ & $21,300,000$ & $4,900,000$ & $7,800,000$ & $27,600,000$ \\
\hline & 2010 & $55,000,000$ & $13,900,000$ & $25,000,000$ & $1,500,000$ & $21,000,000$ & $29,400,000$ \\
\hline \multirow{3}{*}{ Costs } & 2008 & 656,332 & 128,190 & 410,208 & 2,564 & 187,157 & 425,590 \\
\hline & 2009 & $1,579,884$ & 637,428 & 832,959 & 191,620 & 305,027 & $1,079,327$ \\
\hline & 2010 & $2,017,819$ & 509,958 & 917,191 & 55,031 & 770,440 & $1,078,616$ \\
\hline \multirow{3}{*}{$\begin{array}{c}\text { Gross } \\
\text { Margin }\end{array}$} & 2008 & $24,943,668$ & $4,871,810$ & $15,589,792$ & 97,436 & $7,112,843$ & $16,174,410$ \\
\hline & 2009 & $38,820,116$ & $15,662,572$ & $20,467,041$ & $4,708,380$ & $7,494,973$ & $26,520,673$ \\
\hline & 2010 & $52,982,181$ & $13,390,042$ & $24,082,809$ & $1,444,969$ & $20,229,560$ & $28,321,384$ \\
\hline \multirow{3}{*}{ Expenses } & 2008 & $28,573,862$ & $5,580,832$ & $17,858,664$ & 111,617 & $8,148,015$ & $18,528,363$ \\
\hline & 2009 & $45,877,969$ & $18,510,171$ & $24,188,137$ & $5,564,407$ & $8,857,628$ & $31,342,375$ \\
\hline & 2010 & $52,265,171$ & $13,208,834$ & $23,756,896$ & $1,425,414$ & $19,955,792$ & $27,938,109$ \\
\hline \multirow{3}{*}{$\begin{array}{c}\text { Net } \\
\text { Profit/Loss }\end{array}$} & 2008 & $-3,630,194$ & $-709,022$ & $-2,268,871$ & $-14,180$ & $-1,035,172$ & $-2,353,954$ \\
\hline & 2009 & $-7,057,853$ & $-2,847,599$ & $-3,721,096$ & $-856,027$ & $-1,362,655$ & $-4,821,702$ \\
\hline & 2010 & 717,010 & 181,208 & 325,914 & 19,555 & 273,767 & 383,274 \\
\hline
\end{tabular}

Source: Prepared by authors based on data supplied by Sport Club Corinthians Paulista (2009 and 2010). 


\section{Final Considerations}

By considering the objectives of the present study which basically aimed at verifying how the marketing department of a Brazilian soccer club operates and which activities contributed to the highest financial returns, it was possible to verify how the Brazilian soccer team marketing department is run and to compare it with what is proposed by the theory in terms of planning and performing activities related to sports marketing. In addition, it was possible to propose a structure for evaluation of the marketing performance inside a soccer club by identifying the areas responsible for the best results, mainly in terms of financial returns.

It was found that the marketing activities carried out by the club do not follow a structured plan. Nevertheless, each new campaign has a "punctual" planning, and the feasibility of its execution was verified. Though, the lack of a planning clearly defined does not represent an immediate problem for the club management. Since 2008, the revenues generated by the marketing department have represented over $50 \%$ of total revenues. Marketing tools help managing the club, mainly by relying on alternative sources of revenues.

Concern about maintaining a connection with cheerers is perhaps one of the factors responsible for the fact that the Brazilian soccer team studied has the largest fan base in the state of São Paulo, and the second fan base in Brazil. With a larger number of cheerers interested in watching the Brazilian soccer team soccer games, a larger number of TV stations will broadcast such games. Thus, higher revenues generated by transmission rights will be collected, corroborating the fact that the most popular soccer clubs are those benefited by generous agreements signed with TV broadcasting stations.

With better profitability indices achieved by the club, a larger number of games will be broadcasted and, consequently, a larger number of victories, thus increasing consumer satisfaction. This factor is directly related to the marketing department, as when the club wins a larger number of victories the sales of products bearing the club brand get better. The increase in 2010 revenues is also due to the large number of victories won by the club.

Despite the large number of cheerers, the financial conditions of Brazilian soccer teams are not good. Attention paid to cheerers in Brazil is still poor when compared to attention paid by English soccer teams. Therefore, Brazilian soccer teams should be more proactive in relation to the development of a plan for their marketing activities and the respective results obtained.

The model proposed for analysis of the marketing department performance could be utilized by soccer clubs as a means of assessing the activities developed by their respective marketing department. Based on the analysis of the results obtained, it would be possible to adequately plan and structure the activities to be developed. It would also be possible to identify those which need close attention and to improve those which have potential to generate significant returns, as well as those which wouldn't bring any advantage to the club and should perhaps be discarded. Analysis of the financial results of each activity performed by the marketing department would allow structuring the sports marketing plan/planning, and later on make the development of a marketing plan feasible.

By implementing the model proposed, soccer clubs would make practical and theoretical contributions to the sports marketing. Practical in the sense that they would implement their sports marketing activities based on a model; and theoretical, as upon putting the sports marketing plan into practice they would develop the already existing theoretical concepts.

Some limitations concerning the present study are related to the method of research used and to the lack of studies involving the sports marketing activity in Brazil. No comparison with other cases has been made - this is just a suggestion for further studies. Moreover, since the costs utilized were estimated due to lack of data, the results may be biased. However, the evaluation model proposed could be viewed as our contribution both to the theory and the practice of the sports marketing in Brazil. Thinking about the continuity of our present effort, studies focusing other soccer clubs could be a way to check the results herein presented and to compare them with other case studies. In this way, an ideal generic model for analysis of financial results and for structuring the marketing inside soccer clubs might be proposed.

\section{References}

Afif, A. (2000). A bola da vez: O marketing esportivo como estratégia de sucesso. São Paulo: Infinito.

Bauer, H. H., Sauer, N. E., \& Schmitt, P. (2005). Customer-based brand equity in the team sport industry: Operationalization and impact on the economic success of sport teams. European Journal of Marketing, 39(5/6), 496-513. http://dx.doi.org/10.1108/03090560510590683 
Blann, F., \& Armstrong, K. (2003). Sport marketing. In J. Parks \& J. Quarterman (Eds.), Contemporary sport management (2nd ed., pp. 193-217). Champaign, JL: Human Kinetics.

Blumrodt, J., Desbordes, M., \& Bodin, D. (2013). Professional football clubs and corporate social responsibility. Sport, Business and Management: An International Journal, 3(3), 205-225. http://dx.doi.org/10.1108/SBM-04-2011-0050

Brealey, R. A., \& Myers, S. C. (2003). Financing and Risk Management. New York: McGraw-Hill.

Brunoro, J. C., \& Afif, A. (1997). Futebol 100\% profissional. São Paulo: Editora Gente.

Budzinski, O., \& Stazer, J. (2011). Sports business and multisided markets: towards a new analytical framework? Sport, Business and Management: An International Journal, 1(2), 124-137. http://dx.doi.org/10.1108/20426781111146736

Costa, G. (2007, August 9). Marketing esportivo e o futebol brasileiro. Retrieved May 24, 2011, from http://www.universidadedofutebol.com.br/Artigo/949/buscar

Fullerton, S., \& Merz, G. R. (2008). The four domains of sports marketing: A conceptual framework. Sport Marketing Quarterly, 17(2), 90-108.

Garland, R., Brooksbank, R., \& Werder, W. (2011). Strategic marketing's contribution to Australasian golf club performance. Sport, Business and Management: An International Journal, 1(2), 138-154. http://dx.doi.org/10.1108/20426781111146745

Gray, D., \& Mcevoy, C. (2005). Sport marketing strategies and tactics. In B. Parkhouse (Ed.), The management of sport: Its foundation and application (4th ed., pp. 228-255). New York: McGraw-Hill.

Grellet, C. (2000). O marketing do futebol. In A. C. K. Aidar, M. P. Leoncini, \& J. J. Oliveira (Eds.), A nova gestão do futebol (pp. 97-106). Rio de Janeiro: Editora FGV.

Hyatt, C. G., Sutton, W. A., Foster, W. M., \& McConnell, D. (2013). Fan involvement in a professional sport team's decision making. Sport, Business and Management: An International Journal, 3(3), 189-204. http://dx.doi.org/10.1108/SBM-08-2011-0071

Kim, Y. K., \& Trail, G. (2011). A Conceptual Framework for Understanding Relationships Between Sport Consumers and Sport Organizations: A Relationship Quality Approach. Journal of Sport Management, 25(1), 57-69.

Kotler, P., \& Keller, K. L. (2009). Marketing Management (13th ed.). Upper Saddle River: Prentice Hall.

Kuper, S., \& Szymanski, S. (2009). Soccernomics: Why England Loses, Why Germany and Brazil Win, and Why the U.S., Japan, Australia, Turkey - and Even Iraq - Are Destined to Become the Kings of the World's Most Popular Sport. New York: Nation Books.

Leoncini, M. P. (2001). Entendendo o negócio futebol: Um estudo sobre a transformação do modelo de gestão estratégica nos clubes de futebol. Doctoral Thesis, Escola Politécnica, University of São Paulo, São Paulo. Retrieved September 09, 2014, from http://www.teses.usp.br/teses/disponiveis/3/3136/tde-08122003-165621/

Leoncini, M. P., \& Silva, M. T. (2005). Entendendo o futebol como um negócio: Um estudo exploratório. Gestão \& Produção, 12(1), 11-13. http://dx.doi.org/10.1590/S0104-530X2005000100003

Martins, E. (2003). Contabilidade de custos (9th ed.). São Paulo: Atlas.

Matias, A. B. (2007). Análise financeira fundamentalista de empresas. São Paulo: Atlas.

Melo Neto, F. (1998). Administração e marketing de clubes esportivos. Rio de Janeiro: Sprint.

Morrow, S., \& Howieson, B. (2014). The New Business of Football: A Study of Current and Aspirant Football Club Managers. Journal of Sport Management, 28, 515-528. http://dx.doi.org/10.1123/jsm.2013-0134

Pitts, B. G., \& Stotlar, D. K. (2002). Fundamentals of Sport Marketing. (2nd ed.). Morgantown: Fitness Information Tecnology Inc.

Rein, I., Kotler, P., \& Shields, B. (2006). The Elusive Fan: Reinventing Sports in a Crowded Marketplace. New York: McGraw-Hill.

Soares, M. L. (2007a). A miopia do marketing esportivo dos clubes de futebol no Brasil: Proposta de um modelo de gestão de marketing esportivo para os clubes brasileiros. Doctoral Thesis, Faculdade de Economia, Administração e Contabilidade, University of São Paulo, São Paulo. Retrieved September 10, 2014, from http://www.teses.usp.br/teses/disponiveis/12/12139/tde-22082007-125144/ 
Soares, M. L. (2007b). Identificação das barreiras e facilitadores que influenciam na elaboração da estratégia de marketing esportivo nos clubes de futebol no Brasil: Estudo de caso do Grêmio Futebol Porto Alegrense. Paper presented at the Sports International Forum. São Paulo.

Sport Club Corinthians Paulista. (2009). 100 Anos: Relatório de Sustentabilidade 2009. São Paulo.

Sport Club Corinthians Paulista. (2010). Mais de 30 milhões de loucos: Relatório de Sustentabilidade 2010. São Paulo.

Stake, R. E. (2000). Case studies. In N. K. Denzin \& Y. S. Lincoln (Eds.), Handbook of qualitative research (2nd ed., pp. 435-454). Thousand Oaks: Sage.

Tapp, A. (2004). The loyalty of football fans: We'll support you evermore. Journal of Database Marketing \& Customer Strategy Management, 11(3), 203-215. http://dx.doi.org/10.1057/palgrave.dbm.3240221

Yin, R. K. (2008). Case Study Research: Design and Methods (4th ed.). Thousand Oaks: Sage.

Notes

Note 1. Sport Club Corinthians Paulista. More than 30 million fools: 2010 Sustainability Report. São Paulo. 2010, p. 61.

Note 2. Sport Club Corinthians Paulista. More than 30 million fools: Sustainability Report 2010. São Paulo, 2020, p. 37.

Note 3. Amount paid to the holder of a brand, industrial patent, production process, product or original literary work for the rights upon its commercial exploitation.

Note 4. According to the definition given by Michaelis Moderno Dicionário da Língua Portuguesa (Michaelis Modern Portuguese Language Dictionary) and according to the context of the present work, fanatic is a person who is "deeply engajed in a cause" or is "deeply in love with someone".

Note 5. According to data and information collected on http://www.fieltorcedor.com.br/

Note 6. One of HYPERMARCAS, drug manufacturer, and one of the club sponsors.

Note 7. Available on http://www.corinthians.com.br/upload/site/balanco-corinthians.pdf, and http://www.corinthians.com.br/upload/Balanço Corinthians 2009.pdf

Note 8. Available at Sport Club Corinthians Paulista, 2009 and 2010. 